\title{
Den osynliga motparten
}

Recension av Rolf Å. Gustafsson, Från ämbetsmannastat till välfärdsstat. En studie av svensk offentlig arbetsgivarpolitik (Daidalos, Göteborg 2016)

\section{LOVISA BROSTRÖM}

Från ämbetsmannastat till välfärdsstat är en studie av statlig och kommunal arbetsgivarpolitik från I80o-talet fram till 2000-talet. I boken kartläggs viktiga maktcentrum på arbetsmarknaden som är underforskade och historiskt kommit i skymundan av SAF, Svenskt Näringsliv och andra mer framträdande arbetsgivarkonstellationer. Trots att denna offentliga arbetsgivarpolitik rönt så lite uppmärksamhet, har den haft ett stort inflytande, som också ökat i takt med tillväxten av den offentliga sektorn under 1900-talet, en sektor som anställt hundratusentals personer över åren. Att denna utveckling skrivits ner är därför ett välkommet bidrag till forskningen om arbetsmarknaden. Författaren, Rolf Å. Gustafsson, är professor emeritus i sociologi. Han har i flera böcker anlagt historiesociologiska perspektiv på svenska välfärdstjänster och på hur ideologi och styrsystem hänger samman där. I denna bok tar han sig an det längre historiska perspektivet. Det är tydligt att ämnet har framträtt som ett intressantare fält att studera sedan new public management (NPM) kom in i bilden. Gustafsson gör det också klart från början att denna studie, som sträcker sig från I809 års regeringsform, kommer att leda fram till utvecklingen och tillämpningen av NPM inom den offentliga sektorn på 2000-talet. Gustafssons klarspråk kring detta innebär också att man tidigt förstår varför denna historiska studie är viktig för samtiden.

Gustafsson redogör för de olika inställningar som staten har haft som arbetsgivare, från I800-talet, då det inte direkt fanns någon arbetsgivar- 
politisk ideologi för dåtidens ämbetsmän. I takt med att den offentliga sektorn expanderade efter 1930-talet blir ideologin allt tydligare. Under början av 1900-talet började man från statens sida med mera uttänkta organisationsformer, som enligt Gustafsson påminde om hur den privata arbetsmarknaden hade utformat sina organisationer och där han ser rötterna till vad som skulle bli NPM. NPM poppar upp lite varstans och ibland känns det smått anakronistiskt att se rötter till NPM redan från tidigt 1900-tal. Däremot så ger beskrivningen av NPM från 1970-talet en intressant vinkel på hur länge denna organisationstyp funnits och vuxit fram.

Gustafssons bok blir också ett bidrag till kvinnohistorien. Han skriver om hur kvinnor först fick rätt att inneha tjänstemannaarbeten och därefter om hur och varför kvinnors arbetsmarknad, i den offentliga sektorn, sett ut som den gjort. Detta är ett perspektiv som i liten utsträckning visats tidigare. Från statens sida har man kunnat motivera i synnerhet lågt betalda kvinnolöner med ord som "Statens kaka är liten, men säker", vilket i en historisk backspegel har en självuppoffrande klang, där kvinnor skulle vara tacksamma över sin trygghet. De manliga högre tjänstemännen har i stället sökt sig till det privata näringslivet där lönerna varit högre.

Gustafsson har även tidigare skrivit mycket inom detta område: om skola, vård och omsorg i välfärdstjänstearbetet och om förändringar inom äldreomsorgen. I denna bok är det dock svårt att veta vad som är skillnaden på den statliga och kommunala arbetsgivarpolitiken. De klumpas ihop, trots att verksamheterna och förmånerna skiljer sig åt. En tydlig uppdelning mellan stat och kommun skulle ha hjälpt läsaren att förstå sådant som till exempel skollärarnas ändrade arbetssituation när skolan kommunaliserades på 1990-talet. Därför blir begreppet offentlig arbetsgivarpolitik också något förledande eftersom den inte är enhetlig och i boken har en slagsida mot statens arbetsgivarpolitik.

Boken är ett mastigt verk på 500 sidor som i många avseenden påminner om en avhandling. Formen har avhandlingens förtjänster och problem. De många blockcitaten, ibland upp till elva rader långa, hugger upp texten på ett sätt som inte är särskilt läsarvänligt. Ofta är också tolkningen av citat intressantare än citatet i sig, men i denna bok uteblir emellanåt 
tolkningen. En nedbantning av antalet och längden på citaten skulle både ha bidragit till en kortare bok och att de poänger som Gustafsson gör skulle framträtt tydligare. I Från ämbetsmannastat till välfärdsstat finns det också ett rikt persongalleri och det är svårt att veta om det är en centralfigur man står inför, som kommer återkomma, eller om det bara var en ämbetsman som uttryckt sig särskilt pregnant vid ett enskilt tillfälle. Ett så här pass gediget verk skulle också tjäna på en tydligare sammanfattning i slutet, där de huvudsakliga, mycket goda poängerna som Gustafsson gör framhålls, vilka annars har en tendens att försvinna i textmassan. Men den har som sagt även en avhandlings förtjänster. Det är ett omfattande arbete som ligger bakom, det är tydligt vilken tidigare forskning som finns på området och resultaten i boken är väl underbyggda. Det märks att Gustafsson står på fast mark, när han gräver i historien om arbetsgivarpolitik i stat, kommun och landsting.

Sammanfattningsvis är Från ämbetsmannastat till välfärdsstat ett gediget arbete som fyller en lucka inom svensk arbetsmarknadsforskning. Den bidrar också till att man förstår rötterna till new public management och i synnerhet kvinnors arbetsmarknadssituation inom den offentliga sektorn betydligt bättre. Studien blottlägger en av de viktigaste arbetsgivarna under 1900-talet. En arbetsgivare som länge framstått som en i princip osynlig motpart, som inte kaxigt skjutit fram hakan utan i decennier efter decennier verkat ogranskat men haft mycket makt. 


\section{Lasse Kvarnström Ylva Waldemarson \\ Klas Åmark}

\section{I statens tjänst}

\section{Statlig arbetsgivarpolitik och fackliga strategier 1870-1930}

Statens kaka är liten men säker, brukade det heta. Det är knappast sant. Förr i tiden var den hyfsat tilltagen för dem som satt säkert på sina ordinarie jobb men liten och osäker för många andra, inte minst för kvinnorna.

I den här boken har författarna gett sig ut på spaning efter den statliga anställning som flytt, efter den tid då ordinarie tjänster och fasta löneplaner var ideal att sträva efter. Det särpräglade för staten som arbetsgivare var inte så mycket byråkratin - den fanns i de stora företagen också. Men den statliga arbetsgivarpolitiken var politisk, riksdag och regering hade länge ett stort och direkt inflytande över de anställdas löner och anställningsvillkor, och staten hade alldeles speciella krav på sina ordinarie anställda. I utbyte mot trygghet $i$ anställningen var de tvungna att lyda order och de förvägrades rätten att förhandla, sluta avtal och strejka.

Arkiv förlag 1995, mjukband, 284 sidor

»Läs mer om boken på www.arkiv.nu« 